\title{
Comparison of the Effects of Metoclopramide and Ondansetron on Emergency Service Observation Times in Acute Gastroenteritis-Related Nausea and Vomiting Cases
}

\author{
(D) Mustafa Ahmet Afacan, (1) İsmail Tayfur \\ Department of Emergency Medicine, University of Health Sciences, Haydarpasa Numune Training and Research Hospital, Istanbul, Turkey
}

\begin{abstract}
Objectives: The aim of the present study was to compare the effect of metoclopramide and ondansetron treatments on the emergency department observation time in acute gastroenteritis-related nausea and vomiting (NV).

Methods: The study was conducted retrospectively on 297 patients diagnosed with acute gastroenteritis in a training and research hospital's emergency service observation unit within 6 months. Patients with gastroenteritis who were diagnosed with NV were divided into two groups according to the treatment they received in the observation unit. Patients who received 4 mg ondansetron slow infusion therapy were classified as Group 1, and patients who received $10 \mathrm{mg}$ metoclopramide slow infusion therapy were classified as Group 2.

Results: The average age of the patients was $39.57 \pm 18.75$ years. Of the 297 participants, $56.6 \%$ (168) were female. Among them, $51.5 \%$ (153) received ondansetron (Group 1), and 48.5\% (144) received metoclopramide (Group 2). 6.9\% weakness-numbness and $4.9 \%$ akathisia were detected due to metoclopramide use. There were no adverse effects related to ondansetron use. The duration of observation ranged from 19 to $75 \mathrm{~min}$ in Group 1 and from 42 to $122 \mathrm{~min}$ in Group 2. Nineteen (13.2\%) patients in Group 2 and 5 (3.3\%) patients in Group 1 revisited the emergency department within $24 \mathrm{~h}$ due to ongoing complaints.

Conclusion: In conclusion, side effects of weakness and akathisia due to metoclopramide use were observed. However, no side effects were observed due to ondansetron use. Additionally, the use of ondansetron showed a shorter observation time and less recurrent admission to the emergency department. Therefore, ondansetron is a more effective drug in the treatment of NV associated with acute gastroenteritis.

Keywords: Gastroenteritis; metoclopramide; nausea; ondansetron; vomiting.

Please cite this article as "Afacan MA, Tayfur I. Comparison of the Effects of Metoclopramide and Ondansetron on Emergency Service Observation Times in Acute Gastroenteritis-Related Nausea and Vomiting Cases. Med Bull Sisli Etfal Hosp 2019;52(2):186-189".
\end{abstract}

A cute gastroenteritis is defined as the inflammation of the gastrointestinal tract. Nausea and vomiting (NV) are common symptoms of acute gastroenteritis. ${ }^{[1]}$ In addition to causing disturbing and unpleasant feelings in patients, acute gastroenteritis-related nausea and vomiting
(AGNV) may also lead to progressive dehydration. ${ }^{[2]}$ Anticholinergics, antihistamines, corticosteroids, butyrophenones, and benzamides may be used for the treatment of $\mathrm{NV} \cdot{ }^{[3]}$ Metoclopramide is the most commonly preferred for the treatment of AGNV in emergency departments ${ }^{[4]}$ and

Address for correspondence: Mustafa Ahmet Afacan, MD. Haydarpasa Numune Egitim ve Arastirma Hastanesi, Saglik Bilimleri Universitesi, Acil Tip Anabilim Dali, Istanbul, Turkey

Phone: +90 2165423232 E-mail: drmustafaahmet@hotmail.com

Submitted Date: March 17, 2019 Accepted Date: April 15, 2019 Available Online Date: July 11, 2019

${ }^{\circ}$ Copyright 2019 by The Medical Bulletin of Sisli Etfal Hospital - Available online at www.sislietfaltip.org

This is an open access article under the CC BY-NC-ND license (http://creativecommons.org/licenses/by-nc/4.0/).

OPEN ACCESS This is an open access article under the CC BY-NC license (http://creativecommons.org/licenses/by-nc/4.0/). 
is a strong dopamine receptor antagonist by acting as an agonist on serotonin 5-hydroxytryptamine subtype 3 (5HT3) and histamine receptors. ${ }^{[5]}$ Ondansetron is a selective 5 -HT3 receptor antagonist ${ }^{[6]}$ used for the prevention of NV, especially in patients with cancer. ${ }^{[7]}$

In the present study, the efficacy of metoclopramide and ondansetron was evaluated by comparing the duration of observation and repeat admission to the emergency department within $24 \mathrm{~h}$ in patients who presented to the emergency service with complaints of AGNV and who received ondansetron or metoclopramide therapy at the observation unit.

\section{Methods}

The present study was conducted retrospectively on 297 patients who were diagnosed with acute gastroenteritis at the emergency department of a tertiary hospital and administered intravenous therapy due to complaints of $\mathrm{NV}$ at the observation unit within 6 months.

Patients were divided into the metoclopramide-receiving (10 mg) and ondansetron-receiving (4 mg) groups. Patients treated with slow infusion of metoclopramide and ondansetron were included in the study. Patients who underwent additional drug therapy other than ondansetron or metoclopramide in the emergency department were excluded from the study. Demographic data, descriptive characteristics, administered therapy, duration of observation, and repeated admission to the emergency department within $24 \mathrm{~h}$ were recorded for the patients whose files could be obtained. However, patients whose files could not be reached or who had a chronic disease, who underwent repeated drug administration, and who were not taken to the observation unit were also excluded.

\section{Statistical Analysis}

Statistical analyses were conducted using the Number Cruncher Statistical System (NCSS) 2007 Power Analysis and Sample Size (PASS) 2008 statistical software (NCSS; LLC, Kaysville, UT, USA). Descriptive statistical methods (average, standard deviation, median, frequency, ratio, minimum, and maximum) were used for evaluation of the study data. Additionally, the Mann-Whitney $U$ test was used for intergroup comparison of non-normally distributed quantitative variables. The Fisher's exact test was utilized for comparison of qualitative data between the groups. A p value $<0.01$ was accepted as statistically significant.

\section{Results}

The 297 patients included in the study were aged between 18 and 60 years. The average age of the patients was $39.57 \pm 18.75$ years. Of the 297 participants, $56.6 \%$ (168) were female, and $43.4 \%$ (129) were male. Among the patients, $51.5 \%$ (153) received ondansetron, and $48.5 \%$ (144) received metoclopramide (Table 1 ).

The duration of observation ranged from 19 to 75 (average duration 47 \pm 18 ) min in patients receiving ondansetron and from 42 to 122 (average duration $82 \pm 30$ ) min in patients receiving metoclopramide. Therefore, the average duration of observation was significantly longer for patients receiving metoclopramide than for those receiving ondansetron ( $p<0.001$; Table 2).

Repeated admission to the emergency department within $24 \mathrm{~h}$ was also evaluated in the present study. Nineteen (13.2\%) metoclopramide-receiving patients and 5 (3.3\%) ondansetron-receiving patients revisited the emergency department within $24 \mathrm{~h}$ due to ongoing complaints; thus, a significant difference was observed between the groups regarding repeated admissions within $24 \mathrm{~h}$ after the first visit $(p<0.01)$. Of the 19 patients receiving metoclopramide, $6.9 \%^{[10]}$ experienced weakness-drowsiness, and $4.9 \%^{[7]}$ developed akathisia after administration, whereas patients receiving ondansetron did not experience any side effects.

\section{Discussion}

Nausea resulting from AGNV is a frequent cause of admission to emergency departments. Persistent AGNV may also lead to dehydration, and patients are treated with antiemetics along with effective fluid resuscitation. ${ }^{[2]} \mathrm{An}$ ticholinergics, antihistamines, corticosteroids, butyrophenones, and benzamides are the most commonly preferred

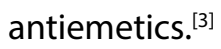

Table 1. Distribution of descriptive characteristics

\begin{tabular}{lcc}
\hline & $\mathbf{n}$ & $\%$ \\
\hline Sex & & \\
$\quad$ Female & 168 & 56.6 \\
$\quad$ Male & 129 & 43.4 \\
Drug & & \\
$\quad$ Metoclopramide & 144 & 48.5 \\
$\quad$ Ondansetron & 153 & 51.5 \\
\hline
\end{tabular}

Table 2. Distribution of observation durations by drugs

\begin{tabular}{|c|c|c|c|}
\hline & Metoclopramide & Ondansetron & $\mathbf{p}$ \\
\hline \multicolumn{4}{|c|}{$\begin{array}{l}\text { Duration of Observation } \\
\text { (minute) }\end{array}$} \\
\hline Min-Max & $42-122$ & $19-75$ & \\
\hline Avg.土SD & $82 \pm 30$ & $47 \pm 75$ & $0.001^{* *}$ \\
\hline
\end{tabular}

${ }^{*}$ Avg: Average. 
Ondansetron is a $5-\mathrm{HT} 3$ receptor antagonist ${ }^{[8]}$ that can block NV caused by 5 -HT3 receptors in the area postrema, nucleus tractus solitarius, and intestinal tract. ${ }^{[9]}$ It can be used in the treatment of resistant NV in emergency services. $^{[10]}$ Significant side effects of ondansetron have not been reported, and it has a significantly longer half-life than metoclopramide. In the present study, $51.5 \%$ of the participants were treated with ondansetron and did not experience any side effects.

Metoclopramide antagonizes 5-HT3 receptors, but its mechanism of antagonizing dopamine D2 receptors is more effective. It has been suggested to increase lower esophageal sphincter tone. ${ }^{[1]]}$ Weakness, drowsiness, dizziness, akathisia, headache, anxiety, and dystonic reactions may be observed due to the use of metoclopramide. In the present study, 144 patients were administered metoclopramide, of whom $6.9 \%$ suffered weakness-drowsiness and $4.9 \%$ experienced akathisia.

Previous prospective studies comparing metoclopramide and ondansetron reported ondansetron to be more effective. ${ }^{[12,13]}$ Similarly, this study evaluating both therapies and their effects on the observation duration of the patients indicated a significant difference in efficacy between the two drugs. The duration of observation was significantly longer for patients receiving metoclopramide than for those receiving ondansetron $(p<0.001)$. We believe that the use of ondansetron in patients presenting to the emergency department with complaints of AGNV significantly shortens the duration of observation, and this is an important effect in different services, such as the emergency observation unit where intensive patient monitoring is performed.

While $13.2 \%{ }^{[19]}$ of the patients receiving metoclopramide revisited the emergency department within $24 \mathrm{~h}$ due to ongoing complaints, only $3.3 \%{ }^{[5]}$ of those receiving ondansetron did so. There was a significant difference between the groups regarding repeated admissions to the emergency department $(p<0.01)$. This finding suggests that ondansetron, which has a significantly longer half-life than metoclopramide, decreases the number of repeated patient admissions to the emergency department within $24 \mathrm{~h}$ after the first visit. If we ignore the price difference in favor of metoclopramide, ondansetron is the right treatment option for persistent NV. ${ }^{[14]}$

\section{Conclusion}

In the present study, weakness-numbness and akathisia were observed due to metoclopramide use. Ondansetron showed shorter observation time, fewer side effects, and less recurrent referral to the emergency department. Owing to these findings, we think that physicians in emer- gency departments should use ondansetron for serious AGNV treatment.

\section{Disclosures}

Ethics Committee Approval: This study was conducted according to principles of Helsinki Declaration. Because the study is retrospective nature, ethical committee approval for this study did not require.

Peer-review: Externally peer-reviewed.

Conflict of Interest: None declared.

Authorship Contributions: Concept - M.A.A., I.T.; Design M.A.A., I.T.; Supervision - M.A.A., I.T.; Materials - M.A.A., I.T.; Data collection \&/or processing - M.A.A., I.T.; Analysis and/or interpretation - M.A.A., I.T.; Literature search - M.A.A., İT.; Writing - M.A.A., I.T.; Critical review - M.A.A., I.T.

\section{References}

1. Eken C. Current Clinical Management Suggestions: Emergency Department Management of a Patient with Acute Diarrhea. Turk J Emerg Med 2011;1:33-9. [CrossRef]

2. Scuderi PE. Int Anesthesiol Clin 2003;41:41-66. [CrossRef]

3. Fujii Y, Saitoh Y, Tanaka H, Toyooka H. Anti-emetic efficacy of prophylactic granisetron, droperidol and metoclopramide in the prevention of nausea and vomiting after laparoscopic cholecystectomy: a randomized, double-blind, placebo-controlled trial. Eur J Anaesthesiol 1998;15:166-71. [CrossRef]

4. Chae J, Taylor DM, Frauman AG. Tropisetron versus metoclopramide for the treatment of nausea and vomiting in the emergency department: A randomized, double-blinded, clinical trial. Emerg Med Australas 2011;23:554-61. [CrossRef]

5. Watcha MF, White PF. Postoperative nausea and vomiting. Its etiology, treatment, and prevention. Anesthesiology 1992;77:16284. [CrossRef]

6. Sandhu T, Tanvatcharaphan P, Cheunjongkolkul V. Ondansetron versus metoclopramide in prophylaxis of nausea and vomiting for laparoscopic cholecystectomy: a prospective double-blind randomized study. Asian J Surg 2008;31:50-4. [CrossRef]

7. Bunce KT, Tyers MB. The role of $5-\mathrm{HT}$ in postoperative nausea and vomiting. Br J Anaesth 1992;69:60S-2S. [CrossRef]

8. Isal JP, Haigh CG, Hellstern K, Inall FC, Joslyn AF, Kanarek BK, et al. The clinical development of ondansetron for use in the prevention and treatment of postoperative nausea and vomiting. Eur J Anaesthesiol Suppl 1992;6:33-6.

9. Simpson K, Spencer CM, McClellan KJ. Tropisetron: an update of its use in the prevention of chemotherapy-induced nausea and vomiting. Drugs 2000;59:1297-315. [CrossRef]

10. Jokar A, Khademhosseini P, Ahmadi K, Sistani A, Amiri M, Sinaki AG. A Comparison of Metoclopramide and Ondansetron Efficacy for the Prevention of Nausea and Vomiting In Patients Suffered From Renal Colic. Open Access Maced J Med Sci 2018;6:1833-8. [CrossRef] 
11. Harmon D, Ryan M, Kelly A, Bowen M. Acupressure and prevention of nausea and vomiting during and after spinal anaesthesia for caesarean section. Br J Anaesth 2000;84:463-7. [CrossRef]

12. Bhatia A, Tripathi KD, Sharma M. Comparison of ondansetron with metoclopramide in prevention of acute emesis associated with low dose \& high dose cisplatin chemotherapy. Indian J Med Res 2003;118:33-41.

13. Helmy SA. Prophylactic anti-emetic efficacy of ondansetron in laparoscopic cholecystectomy under total intravenous anaesthesia. A randomised, double-blind comparison with droperidol, metoclopramide and placebo. Anaesthesia 1999;54:266-71.

14. Wu SJ, Xiong XZ, Cheng TY, Lin YX, Cheng NS. Efficacy of ondansetron vs. metoclopramide in prophylaxis of postoperative nausea and vomiting after laparoscopic cholecystectomy: a systematic review and meta-analysis. Hepatogastroenterology 2012;59:2064-74. [CrossRef] 